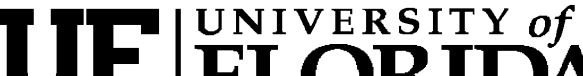 FLORIDA \\ IFAS Extension
}

\section{Crossbreeding Systems in Beef Cattle ${ }^{1}$}

\author{
Gary R. Hansen²
}

As selection for carcass quality has taken center stage in the beef cattle industry, cattle producers have adopted strategies that have decreased the use of crossbreeding in beef cattle herds. Crossbreeding leads to increased performance without any added costs or inputs. It is one of the few management that increase productivity and improve the line when properly used. Despite the benefits of the practice, however, cattle producers have adopted strategies that have decreased the use of crossbreeding in beef cattle herds because selection for carcass quality has primary importance in the beef cattle industry.

Crossbreeding works as a result of heterosis, also known as hybrid vigor. Hybrid vigor is the amount by which crossbred animals exceed (or differ from) the average of the purebred parents used in the cross (expressed in units or percent). This idea can best be illustrated through the example listed below for weaning weight.

Brahman average $500 \mathrm{lbs}$

Angus average $550 \mathrm{lbs}$

Average of purebreds $525 \mathrm{lbs}$

Average of crossbred progeny $575 \mathrm{lbs}$ -

\section{(1/2 Brahman 1/2 Angus)}

Hybrid vigor $=575-525=50 \mathrm{lbs}$ difference

Percent hybrid vigor 50/525 $=9.52 \%$

Hybrid vigor is expressed in almost all beef cattle production traits, especially in reproduction and adaptability traits. Table 1 explains the relationship between heritability and heterosis regarding different categories of beef cattle traits. Since reproduction and maternal traits have low heritability, response to selection will be slow. At the same time, significant improvement in these traits can be made through programs that maximize heterosis. The inverse is true with product or carcass traits. Significant and rapid progress can be made through selection for carcass traits, while crossbreeding has little or no effect. Growth traits are moderate for both heritability and heterosis, making progress possible through selection and crossbreeding.

Using this information, commercial producers can tailor a program to fit their individual needs. If a producer is concerned about carcass characteristics, then selection is the best way to improve quality. On the other hand, if reproductive rates need to be enhanced, crossbreeding is the quickest and easiest

1. This document is AN165, one of a series of the Animal Science Department, Florida Cooperative Extension Service, Institute of Food and Agricultural Sciences, University of Florida. Original publication date September, 2006. Visit the EDIS Web Site at http://edis.ifas.ufl.edu.

2. Hansen, G.R., Assistant Professor of Animal Science, North Florida Research and Education Center Marianna, Cooperative Extension Service, Institute of Food and Agricultural Sciences, University of Florida, Gainesville, 32611.

The Institute of Food and Agricultural Sciences (IFAS) is an Equal Opportunity Institution authorized to provide research, educational information and other services only to individuals and institutions that function with non-discrimination with respect to race, creed, color, religion, age, disability, sex, sexual orientation, marital status, national origin, political opinions or affiliations. U.S. Department of Agriculture, Cooperative Extension Service, University of Florida, IFAS, Florida A. \& M. University Cooperative Extension Program, and Boards of County Commissioners Cooperating. Larry Arrington, Dean 
way to improve. It should be realized that no one breed is best at everything. Producers should use breeds that complement each other. For example, breeds that have low marbling would need to be mated to animals with high marbling potential. Continental animals and British animals are good examples of breeds that complement each other. It also should be noted that breeds from diverse genetic backgrounds will express higher levels of hybrid vigor when crossed. For example, British breeds crossed with each other will result in hybrid vigor, but at lower levels than British breeds crossed with Continental or Bos indicus (Zebu) breeds (Table 2). It should be stressed that there needs to be a planned program if expected results are to occur. In the past, producers have thought of crossbreeding as simply replacing bulls every 2 to 3 years with whatever breed was popular at the time. This has lead to problems with uniformity of the resulting product. Quality cattle need to be selected in order for crossbred cattle to out-perform straightbred cattle and produce the type of product that is in demand by the consumer. Crossbreeding will not overcome poor genetics.

Crossbreeding can be a very effective tool to improve reproductive and weaning rates in beef cattle. Table 3 shows the results of Charolais bulls naturally mated to various types of purebred and crossbred cows. All cows were managed in a single herd and data was collected over a three-year period. Cows were located in central Texas. Weaning weights were adjusted to 205 days as well as for age of dam. Records from first-calf heifers were excluded.

Weaning weight per cow exposed to breeding is the best figure to sum up production efficiency. The calculation includes reproduction and gestation efficiency, calving management and survival from birth to weaning. Using the above data, the difference in the Hereford versus the Brahman X Hereford cows was 211 pounds of extra weaning weight per cow exposed. This points out the advantage of using crossbred cows, especially Bos indicus (Bi) X Bos taurus (Bt) breed types. Olson et al., 1991, compared different crossbred cattle in Nebraska and Florida.

The study showed that Bos indicus X Bos taurus cows weaned calves approximately equal in weaning weight per cow exposed in Florida and Nebraska, but weaned 62 and 34 more pounds in comparison than Bos taurus X Bos taurus cows in Florida and Nebraska, respectively. The Zebu productivity advantage in Florida was up to three times greater than that experienced in Nebraska.

Using various systems of crossbreeding can have a significant impact. The various systems of crossbreeding yield different results in a beef cattle operation. Table 4 summarizes some of the more popular crossbreeding programs available for commercial producers to use. The estimated herd production factor uses the straightbred herd as the baseline. Each system should be carefully analyzed before implementing the program in a commercial operation. Some systems will not work for small producers. Others require a stable source from which quality replacement females can be purchased. Each system has advantages and disadvantages. However, cattle producers should find a way to capture hybrid vigor in their herd.

Estimated herd production factor is the increase in production that would be realized in each crossbreeding system. Notice that the F-1 Cow/Terminal calf system results in the highest percent of heterosis expressed in a crossbreeding system with a factor of 1.25 while the straightbred herd is 1.00 . This simply means that using the F-1 Cow/ Terminal calf system will result in a $25 \%$ increase in production. However, the other factors should be considered before determining which crossbreeding system to use.

In summary:

- Breeds from diverse environments (genetic backgrounds) express more total heterosis in the maternal and individual.

- Breeds should be matched to complement each other. Use animals that will work in your envirmoment and management system.

- Source of replacements must be considered in order to insure that the crossbreeding program will work. 
- Heterosis cannot overcome a poor quality genetic base. Use quality animals when selecting bulls to use in your herd.

- Use breeds that will be the most economically productive for your operation and management style.

- Commit to a crossbreeding system and stick to it. Do not become the bull of the month club with your bull battery..

\section{Reference}

Olson, TA, K. Euclides Filho, L. V. Cundiff, M. Koger, W.T. Butts, Jr, and K.E. Gregory. Effects of breed group location interaction on crossbred cattle in Nebraska and Florida. J. Anim. Sci 69:104-114 
Table 1. Expression of heritability and heterosis in traits of economic importance in beef cattle production

\begin{tabular}{||l|l|c||}
\hline \hline Trait & \multicolumn{1}{|c||}{ Heritability \% } & Heterosis \% \\
\hline Reproduction & Low (5-12\%) & 20 \\
\hline Maternal & Low to Moderate $(>20 \%)$ & 15 \\
\hline Growth & Moderate (20-40) & $5-12$ \\
\hline Product & High (40-50) & $\mathrm{NIL}^{*}$ \\
\hline *insignificant & \\
\hline
\end{tabular}

Table 2. Average heterosis in the economically important beef traits when crossing divergent breed types of cattle.

\begin{tabular}{|lcc|}
\hline \hline Trait & Bos taurus X Bos taurus \% & Bos indicus X Bos taurus \% \\
\hline Individual Heterosis & & \\
(Calf Performance) & 2.4 & 11.1 \\
$\quad$ Birth weight & 3.9 & 12.6 \\
Weaning weight & 2.6 & 16.2 \\
Post-weaning gain & & \\
& & \\
Maternal Heterosis & 3.7 & 13.4 \\
(Cow Performance) & 1.5 & 5.1 \\
Calving rate & 1.8 & 5.8 \\
Calf survival & 3.9 & 16.0 \\
Birth weight & & \\
Weaning weight & & \\
\hline Adapted from Cundiff et al., 1994 & & \\
\hline \hline
\end{tabular}

Table 3.

\begin{tabular}{||l|c|c|c||}
\hline \hline Cow Type & $\begin{array}{c}\% \\
\text { Pregnant }\end{array}$ & $\begin{array}{c}\text { Weaning } \\
\text { Wt (Lbs) }\end{array}$ & $\begin{array}{c}\text { No of } \\
\text { Records }\end{array}$ \\
\hline Hereford & 82 & 492 & 52 \\
\hline Angus & 84 & 498 & 68 \\
\hline Brahman & 79 & 513 & 37 \\
\hline Angus Cross & 86 & 523 & 63 \\
\hline Brahman X Hereford & 97 & 619 & 128 \\
\hline Angus X Brahman & 96 & 612 & 89 \\
\hline Hansen, unpublished data & & \\
\hline
\end{tabular}


Table 4. Estimated Weaning Weight Performance Factors for Various Crossbreeding Systems

\begin{tabular}{|c|c|c|c|c|c|c|}
\hline System & $\begin{array}{l}\text { Breed } \\
\text { Complementarity } \\
\text { Potential }\end{array}$ & $\begin{array}{l}\text { Management } \\
\text { Ease }\end{array}$ & $\begin{array}{l}\text { Calf } \\
\text { Heterosis } H_{i}\end{array}$ & $\begin{array}{l}\text { Maternal } \\
\text { Heterosis } \\
\mathrm{H}_{\mathrm{m}}\end{array}$ & $\begin{array}{l}\text { Hiefer } \\
\text { Replacements }\end{array}$ & $\begin{array}{l}\text { Estimated } \\
\text { Herd } \\
\text { Production } \\
\text { Factor }\end{array}$ \\
\hline $\begin{array}{l}\text { Straightbred } \\
\text { Herd }^{1}\end{array}$ & No & + & $0 \%$ & $0 \%$ & Raised & 1.00 \\
\hline $\begin{array}{l}\text { F-1 Cow } \\
\text { System }\end{array}$ & Yes & + & $100 \%$ & $0 \%$ & Purchased & 1.10 \\
\hline $\begin{array}{l}\text { F-1 Cow } \\
\text { Terminal } \\
\text { Calf }^{3}\end{array}$ & Yes & + & $100 \%$ & $100 \%$ & Purchased & 1.25 \\
\hline $\begin{array}{l}\text { 2-Breed } \\
\text { Rotation }\end{array}$ & No & - & $67 \%$ & $67 \%$ & Raised & 1.17 \\
\hline $\begin{array}{l}\text { 3-Breed } \\
\text { Rotation }\end{array}$ & No & - & $85.7 \%$ & $85.7 \%$ & Raised & 1.21 \\
\hline $\begin{array}{l}\text { 4-Breed } \\
\text { Composite }^{6}\end{array}$ & No & + & $75 \%$ & $75 \%$ & Raised & 1.19 \\
\hline \multicolumn{7}{|c|}{$\begin{array}{l}{ }^{1} \text { Straightbred Herd- Cows and bulls from the same breed are mated. } \\
{ }^{2} \mathrm{~F}-1 \text { Calf System- Cows from one breed are mated to bulls of another breed. All calves are marketed with } \\
\text { replacements coming from an outside source. } \\
{ }^{3} \mathrm{~F}-1 \text { Cow/Terminal Calf- F- } 1 \text { cows are mated to a breed that is different for the parent breeds of the F- } 1 \text { cow. All } \\
\text { calves are marketed and replacements are purchased. } \\
{ }^{4} 2 \text {-Breed Rotation- Two breeds are mated by crisscrossing between breeds. Cows from breed A are mated to bulls } \\
\text { of breed B and vice versa. } \\
{ }^{5} 3 \text {-Breed Rotation- Three breeds are mated in rotation. Cows from breed A are mated to bulls from breed B. } \\
\text { Daughters from this cross (1/2 A } 1 / 2 \text { B) are mated to bulls of breed C. Daughters from this cross ( } 1 / 4 \text { A } 1 / 4 \text { B } 1 / 2 \mathrm{C}) \\
\text { are mated to bulls of breed A. The rotation continues on in this fashion for as long as the system is used in the herd. } \\
{ }^{6} 4-\text { Breed Composite- Use of four breeds in the development of a composite animal that has an exact percent of } \\
\text { each breed in its genetic make up. }\end{array}$} \\
\hline
\end{tabular}

